\title{
Effect of Processing On Selected Nutrients of Beans (Phaseolus vulgaris) ${ }^{1}$
}

\author{
Edelmiro J. Rodriguez-Sosa, Sara Villafañe de Colom, and \\ Orlando Parsi-Ros ${ }^{2}$
}

\begin{abstract}
Twenty-two selections of dry beans (Phaseolus vulgaris) were commercially canned and analyzed for $\mathrm{Ca}, \mathrm{Mg}, \mathrm{Fe}, \mathrm{Mn}, \mathrm{P}, \mathrm{Na}, \mathrm{Cl}, \mathrm{K}$, protein $(\mathrm{N} \times 6.25)$, and fat content before and after processing. The retention percent for $\mathrm{Mg}, \mathrm{Fe}, \mathrm{Mn}$, $\mathrm{P}$, and $\mathrm{K}$ were $89,95,89.8,67.4$, and 55.4 , respectively. The $\mathrm{Ca}, \mathrm{Na}$, and $\mathrm{Cl}$ contents increased with processing. The increase in $\mathrm{Ca}$ content can be attributed to the hardness of processing water. $\mathrm{Na}$ and $\mathrm{Cl}$ were added as table salt. When all selections are taken into account, no significant differences were observed between raw dry and processed beans with respect to $\mathrm{Fe}, \mathrm{Mn}$, protein, and fat content, but there were significant differences with respect to $\mathrm{Ca}, \mathrm{Mg}, \mathrm{P}, \mathrm{Na}, \mathrm{Cl}$, and $\mathrm{K}$.
\end{abstract}

\section{INTRODUCTION}

Food legumes, especially beans, are an important source of protein, calories, and minerals in the diet of many countries. A substantial amount of the legumes consumed in Puerto Rico are beans canned in brine.

Food preservation plays an important role in providing a year round supply of foods. However, processing methods such as blanching and commercial sterilization influence the nutrient content of foods (8). The genetic makeup or variety as well as the growing conditions, also influence the nutrient content of foods (7). Thus, through selective breeding Hein and Hutchings (9) raised the vitamin A content of squash ten-fold and at the same time achieved an increase in its ascorbic acid content.

Loss of minerals from foods occurs as a result of leaching or extraction mainly during blanching and cooking operations, and the degree of loss depends upon the solubility of the mineral salts $(8,14)$. Depending chiefly upon the temperature and the length of storage time (10) changes continue to take place in canned foods after processing. However, under most processing conditions and according to Barrat (3), the mineral as well as the protein content of foods remains fairly stable. Heating of proteins, on the other hand, can cause loss of nutritive value because of the highly reactive nature of amino acids such as lysine and methionine (12) with reactive functional groups.

Elkins et al. (5) found that for green beans the hardness of the

${ }^{1}$ Manuscript submitted to Editorial Board January 17, 1983.

${ }^{2}$ Food Technologist, Associate Chemist, and Research Assistant, respectively, Food Technology Laboratory and Central Analytical Laboratory, Agricultural Experiment Station, University of Puerto Rico, Mayagüez Campus, Río Piedras, P. R. Dr. José BadilloFeliciano provided the bean samples. 
blanching water and the canning brine affect the retention of minerals in the solid portion and may cause a gain in minerals such as calcium, magnesium, and potassium.

Augustin et al. (2) found that nutrient variability in Phaseolus vulgaris beans freshly harvested while low in some minerals, eg, phosphorus and potassium was higher in other minerals studied such as manganese, iron, magnesium, calcium, and sodium. They also found that retention values after cooking in plain water generally exceeded $80 \%$, except for sodium retention, which was in the range of $40 \%$.

This research was undertaken to study the variability of the mineral content of various bean selections.

\section{MATERIALS AND METHODS}

Twenty-two selections of beans (kidney, white, and striped) were analyzed in this experiment. Beans were harvested at the Isabela Substation of the Agricultural Experimental Station located in the northwest of the Island. Beans were planted in winter. They were left to dry in the field before being harvested. Samples were brought to the Food Technology Laboratory and stored under controlled conditions $\left(24^{\circ} \mathrm{C}\right.$ and $60 \% \mathrm{RH}$ ) until used.

Canned beans were prepared by the commercial processing method, which consists in rehydration of the beans until doubling their dry weights, sorting, canning in $2 \%$ hot brine solution, exhausting in a vapor tunnel, and thermally processing in a retort at $15 \mathrm{lb} / \mathrm{in}^{2}$ for about $20 \mathrm{~min}$ until $250^{\circ} \mathrm{F}\left(121^{\circ} \mathrm{C}\right)$ is reached.

For the nutrient analyses, the dry beans were ground to 40 mesh $(0.420$ $\mathrm{mm}$ ). Canned samples were drained and the liquid portion discarded. The drained beans were dried in a force ventilated oven at $60^{\circ} \mathrm{C}$ and ground to 40 mesh.

Beans were then analyzed for $\mathrm{Ca}, \mathrm{Mg}, \mathrm{Fe}, \mathrm{Mn}, \mathrm{P}, \mathrm{Na}, \mathrm{K}, \mathrm{Cl}$, protein and ether extracts (fat). All analyses were performed on a dry weight basis. For mineral analyses, samples were dry ashed according to the A.O.A.C. (1).

Fat and $\mathrm{Cl}$ were determined according to the A.O.A.C. (1); $\mathrm{Ca}, \mathrm{Mg}, \mathrm{Na}$, and $\mathrm{K}$ were determined by flame photometry, essentially as in the A.O.A.C. (1). P was determined by the method described by Fiske and Subbarrow (6), and $\mathrm{N}$ by the method described by Russell (17), both methods as modified by Technicon Co. (1960) and subsequently by Riera and Rivera Nuñez (15). Fe and Mn were determined spectrophotometrically by the orthophenanthroline and periodate methods, respectively, as described by Rubins (16), and modified for plant materials.

Results of these evaluations were submitted to analysis of variance 
and the differences were compared with Duncan's multiple range test $(11,13)$.

\section{RESULTS AND DISCUSSION}

Table 1 summarizes the ranges in mineral, protein and fat composition of the bean selections studied, and table 2 shows the percentage gained or retained of the analyzed nutrients.

Calcium content in raw dry white beans was higher than in kidney and striped selections. However, in processed beans Ca content was significantly higher in kidney beans than in raw dry beans. This increase can be attributed to minor amounts of $\mathrm{Ca}$ in the water used for processing (8). The increase in Ca content was $25.28 \%$. The highest increase in Ca content $(33 \%)$ was in the white selection. The highest content of Ca was observed in Calima selection, but no significant differences were observed among Calima and Oro Rico, Bonita \#4, Bonita \#7, Abrams Africa, and Galana selections.

Magnesium content was lower in kidney beans, and there was no significant difference between raw dry and processed beans. The $\mathrm{Mg}$ content of white and striped beans was significantly higher in raw dry than in processed beans. The average $\mathrm{Mg}$ retention was $89 \%$, which is considerably high. The $\mathrm{Mg}$ content after canning varied from $105.9 \%$ in Calima selection to $73 \%$ in Galana.

No significant differences were found between raw dry and processed beans or among selections with respect to $\mathrm{Fe}$ content. However, $\mathrm{Fe}$ content was higher in the raw dry beans than in processed beans. The Fe content in some bean selections increased. This increase can be attributed to minor amounts of $\mathrm{Fe}$ in the processing water and to absorption from the brine and from the can. Generally, the average Fe retention was $95 \%$.

There were no significant differences in Mn between raw and processed beans or among the different varieties. The average difference in $\mathrm{Mn}$ between raw and processed beans was only $4.0 \mathrm{mg} / 100 \mathrm{~g}$. The average retention of Mn was $89.8 \%$.

Phosphorus was significantly higher in raw than in processed beans for all varieties. The average $\mathrm{P}$ retention was $67.4 \%$. The highest $\mathrm{P}$ content was found in Cuarentena selection, but this content was not significantly higher when compared with Bonita \#4, Bonita \#7, Bonita \#8, Colombia 91P, Galana, White 117, and Pompadour Dominicana.

A highly significant difference was observed between the $\mathrm{Na}$ content of raw dry and processed beans. This substantial increase in $\mathrm{Na}$ was expected since $2 \%$ table salt was added to the brine solution. The average $\mathrm{Na}$ percent increase was 97.6. Differences among selections were not significant. 
TABLE 1.-Selected nutrient content of dry and processed beans (Phaseolus vulgaris) per $100 \mathrm{~g}$

\begin{tabular}{|c|c|c|c|c|c|c|c|c|c|c|c|c|c|c|c|c|c|c|c|c|c|}
\hline \multirow{2}{*}{ Variety } & \multirow{2}{*}{ Selection } & \multicolumn{10}{|c|}{ Raw (dry) } & \multicolumn{10}{|c|}{ Processed } \\
\hline & & $\mathrm{Ca}$ & $\mathrm{Mg}$ & $\mathrm{Fe}$ & $\mathrm{Mn}$ & $\mathrm{P}$ & $\mathrm{Na}$ & $\mathrm{Cl}$ & $\mathrm{K}$ & Protein & Fat & $\mathrm{Ca}$ & $\mathrm{Mg}$ & $\mathrm{Fe}$ & $\mathrm{Mn}$ & $\mathrm{P}$ & $\mathrm{Na}$ & $\mathrm{Cl}$ & K & Protein & Fat \\
\hline \multirow{5}{*}{ Kidney } & & $m g$ & $m g$ & $m g$ & $m g$ & $m g$ & $m g$ & $m g$ & $g$ & $g$ & $g$ & $m g$ & $m g$ & $m g$ & $m g$ & $m g$ & $m g$ & $g$ & $g$ & $g$ & $g$ \\
\hline & Violeta & 110 & 160 & 4.3 & 2.5 & 530 & 20 & 20 & 1.94 & 20.44 & 0.90 & 140 & 150 & 2.6 & 2.4 & 340 & 910 & 1.35 & 1.04 & 21.04 & 1.81 \\
\hline & Lajas & 80 & 150 & 3.2 & 1.9 & 590 & 20 & 20 & 1.93 & 21.36 & 0.92 & 90 & 120 & 5.1 & N.D. & 370 & 940 & 1.38 & 0.67 & 22.12 & 1.56 \\
\hline & $1973(28)$ & 90 & 140 & 3.3 & 1.9 & 560 & 20 & 20 & 1.96 & 23.41 & 0.94 & 110 & 140 & 2.5 & 1.4 & 370 & 930 & 1.32 & 1.06 & 23.73 & 1.84 \\
\hline & $27 \mathrm{R}$ & 100 & 170 & 4.9 & 1.7 & 555 & 30 & 20 & 1.96 & 23.30 & 0.93 & 110 & 140 & 3.2 & 0.4 & 360 & 930 & 1.36 & 1.06 & 22.01 & 0.72 \\
\hline \multirow[t]{7}{*}{ White } & Bonita \#4 & 140 & 210 & 6.5 & 2.1 & 620 & 40 & 30 & 2.12 & 26.00 & 0.86 & 220 & 180 & 4.9 & 1.1 & 430 & 1000 & 1.43 & 1.25 & 25.79 & 0.88 \\
\hline & Bonita \#7 & 140 & 220 & 6.4 & 1.7 & 630 & 20 & 20 & 2.06 & 25.35 & 0.71 & 210 & 170 & 5.9 & 2.8 & 420 & 920 & 1.41 & 1.09 & 26.11 & 0.74 \\
\hline & Bonita \#8 & 120 & 200 & 8.5 & 1.9 & 620 & 20 & 20 & 2.22 & 24.00 & 1.00 & 180 & 180 & 4.7 & 2.4 & 430 & 970 & 1.41 & 1.15 & 25.73 & 0.63 \\
\hline & Abrams Africa & 150 & 180 & 6.8 & 2.1 & 560 & 20 & 20 & 2.00 & 23.95 & 0.93 & 220 & 170 & 9.9 & 1.5 & 380 & 960 & 1.41 & 1.12 & 24.54 & 0.69 \\
\hline & Cuarentena & 120 & 180 & 3.2 & 1.4 & 650 & 20 & 10 & 1.97 & 25.78 & 1.04 & 180 & 170 & 8.4 & 1.4 & 430 & 950 & 1.36 & 1.09 & 25.16 & 0.75 \\
\hline & White 142 & 150 & 200 & 3.6 & 2.1 & 570 & 20 & 20 & 2.07 & 23.75 & 1.26 & 220 & 170 & 4.3 & 1.2 & 380 & 960 & 1.42 & 1.18 & 25.46 & 1.11 \\
\hline & White 117 & 140 & 200 & 6.6 & 1.4 & 590 & 20 & 20 & 2.08 & 25.89 & 0.78 & 210 & 170 & 6.6 & 3.5 & 400 & 1000 & 1.45 & 1.16 & 25.78 & 0.50 \\
\hline \multirow[t]{11}{*}{ Pinto } & Dominicana \#5 & 100 & 160 & 4.1 & 1.4 & 570 & 20 & 20 & 1.88 & 21.84 & 0.99 & 130 & 160 & 4.8 & 1.4 & 370 & 950 & 1.36 & 1.03 & 22.38 & 1.66 \\
\hline & Naranjito & 80 & 150 & 3.2 & 0.7 & 540 & 30 & 20 & 1.88 & 20.50 & 1.09 & 110 & 150 & 2.5 & 1.4 & 350 & 910 & 1.30 & 1.03 & 21.04 & 1.44 \\
\hline & $\begin{array}{l}\text { Pompadour } \\
\text { Dominicana }\end{array}$ & 110 & 160 & 3.8 & 1.9 & 540 & 20 & 20 & 1.88 & 21.36 & 0.95 & 130 & 160 & 5.2 & 0.7 & 430 & 950 & 1.36 & 1.25 & 22.74 & 1.00 \\
\hline & Galana & 170 & 230 & 10.9 & 4.1 & 560 & 20 & 40 & 1.71 & 24.75 & 0.95 & 210 & 170 & 3.6 & 3.2 & 940 & 950 & 1.39 & 1.16 & 24.49 & 1.16 \\
\hline & Borinquen & 100 & 170 & 5.0 & 2.8 & 560 & 20 & 20 & 1.93 & 23.62 & 0.96 & 100 & 140 & 6.8 & 1.9 & 380 & 970 & 1.47 & 1.11 & 24.06 & 1.13 \\
\hline & Pompadour & 90 & 170 & 6.8 & 1.1 & 530 & 20 & 20 & 1.85 & 24.16 & 0.98 & 130 & 160 & 3.2 & 2.1 & 390 & 970 & 1.46 & 1.09 & 23.95 & 1.39 \\
\hline & Colombia 91P & 120 & 180 & 5.4 & 5.0 & 630 & 20 & 40 & 2.02 & 25.30 & 1.13 & 180 & 160 & 1.7 & 1.1 & 380 & 950 & 1.43 & 1.22 & 21.36 & 1.34 \\
\hline & Calima & 170 & 170 & 7.0 & 2.5 & 560 & 30 & 30 & 2.02 & 21.58 & 1.64 & 220 & 180 & 5.3 & 1.9 & 390 & 1060 & 1.48 & 1.17 & 20.28 & 1.47 \\
\hline & Rosita Lajas & 70 & 190 & 3.2 & 1.0 & 530 & 30 & 20 & 2.06 & 23.30 & 1.11 & 110 & 160 & 4.8 & 2.1 & 330 & 1000 & 1.43 & 1.11 & 23.19 & 1.69 \\
\hline & Oro Rico & 130 & 200 & 5.2 & 2.5 & 550 & 20 & 40 & 1.97 & 20.28 & 1.39 & 180 & 160 & 1.9 & 2.1 & 350 & 930 & 1.37 & 1.03 & 21.58 & 1.97 \\
\hline & Guayamesa & 80 & 160 & 5.8 & 1.9 & 530 & 20 & 30 & 1.86 & 22.65 & 1.00 & 110 & 140 & 1.7 & 0.8 & 350 & 910 & 1.34 & 1.02 & 22.87 & 1.68 \\
\hline
\end{tabular}


TABLE 2.-Percent increase or retained of selected nutrients during canning of various bean (Phaseolus vulgaris) selections

\begin{tabular}{|c|c|c|c|c|c|c|c|c|c|c|c|}
\hline Variety & Selection & $\mathrm{Ca}$ & $\mathrm{Mg}$ & $\mathrm{Fe}$ & $\mathrm{Mn}$ & $\mathrm{P}$ & $\mathrm{Na}$ & $\mathrm{Cl}$ & $\mathrm{K}$ & Protein & Fat \\
\hline \multirow[t]{4}{*}{ Kidney } & Violeta & $21.4^{* 1}$ & 93.8 & 60.5 & 96.0 & 64.2 & $97.8^{*}$ & $98.5^{*}$ & 53.6 & $2.9^{*}$ & $50.3^{*}$ \\
\hline & Lajas & $11.1^{*}$ & 80.0 & $37.4^{*}$ & N.D. ${ }^{2}$ & 62.7 & $97.8^{*}$ & $98.6^{*}$ & 34.7 & $3.4^{*}$ & $41.0^{*}$ \\
\hline & $1973(28)$ & $18.2^{*}$ & 100.0 & 75.8 & 73.7 & 66.1 & $97.9^{*}$ & $98.5^{*}$ & 54.1 & $1.4^{*}$ & $48.9^{*}$ \\
\hline & $27 \mathrm{R}$ & $9.1^{*}$ & 82.4 & 65.3 & 23.5 & 65.5 & $96.8^{*}$ & $98.5^{*}$ & 54.1 & 94.5 & 77.4 \\
\hline \multirow[t]{7}{*}{ White } & Bonita \#4 & $36.4^{*}$ & 85.7 & 75.4 & 52.4 & 69.4 & $96.0^{*}$ & $97.9^{*}$ & 59.0 & $6.5^{*}$ & $2.3^{*}$ \\
\hline & Bonita \#7 & $33.3^{*}$ & 77.3 & 92.2 & 16.5 & 66.7 & $97.8^{*}$ & $98.6^{*}$ & 53.9 & $2.9^{*}$ & $4.6^{*}$ \\
\hline & Bonita \#8 & $33.3^{*}$ & 90.0 & 55.3 & $20.8^{*}$ & 69.4 & $97.9^{*}$ & $98.6^{*}$ & 51.8 & $6.7^{*}$ & 63.0 \\
\hline & Abrams Africa & $31.8^{*}$ & 94.4 & $34.4^{*}$ & 71.4 & 67.9 & $97.9^{*}$ & $98.6^{*}$ & 50.9 & $2.4^{*}$ & 74.2 \\
\hline & Cuarentena & $33.3^{*}$ & 94.4 & $61.9^{*}$ & 100.0 & 66.2 & $97.9^{*}$ & $99.3^{*}$ & 55.3 & 97.6 & 53.6 \\
\hline & White 142 & $31.8^{*}$ & 85.0 & $16.3^{*}$ & 57.1 & 66.7 & $97.9^{*}$ & $98.6^{*}$ & 57.0 & $6.7^{*}$ & 88.1 \\
\hline & White 117 & $33.3^{*}$ & 85.0 & 100.0 & $60.0^{*}$ & 67.8 & $98.0^{*}$ & $98.6^{*}$ & 55.8 & 99.6 & 64.1 \\
\hline \multirow[t]{11}{*}{ Striped } & Dominicana \#5 & $23.1^{*}$ & 100.0 & $14.6^{*}$ & 100.0 & 64.9 & $97.9^{*}$ & $98.5^{*}$ & 54.8 & $2.4^{*}$ & $40.4^{*}$ \\
\hline & Naranjito & $27.3^{*}$ & 100.0 & 78.1 & $50.0^{*}$ & 64.8 & $96.7^{*}$ & $98.5^{*}$ & 54.8 & $2.6^{*}$ & $24.3^{*}$ \\
\hline & $\begin{array}{l}\text { Pompadour } \\
\text { Dominicana }\end{array}$ & $15.4^{*}$ & 100.0 & $26.9^{*}$ & 36.8 & 79.6 & $97.9^{*}$ & $98.5^{*}$ & 66.5 & $2.6^{*}$ & $5.0^{*}$ \\
\hline & Galana & $19.1^{*}$ & 73.9 & 33.0 & 78.0 & 78.6 & $97.9^{*}$ & $97.1^{*}$ & 67.8 & 98.9 & $18.1^{*}$ \\
\hline & Borinquen & 0 & 82.4 & 26.5 & 67.9 & 67.9 & $97.9^{*}$ & $98.6^{*}$ & 57.5 & $1.8^{*}$ & $15.1^{*}$ \\
\hline & Pompadour & $30.8^{*}$ & 94.1 & 47.1 & $47.6^{*}$ & 73.6 & $97.9^{*}$ & $98.6^{*}$ & 58.9 & 99.1 & $29.5^{*}$ \\
\hline & Colombia 91P & $33.3^{*}$ & 88.9 & 31.5 & 22.0 & 60.3 & $97.9^{*}$ & $97.2^{*}$ & 60.4 & 84.4 & $15.7^{*}$ \\
\hline & Calima & $22.7^{*}$ & $5.6^{*}$ & 75.7 & 76.0 & 69.6 & $97.2^{*}$ & $98.7^{*}$ & 57.9 & 94.0 & 89.6 \\
\hline & Rosita Lajas & $36.4^{*}$ & 84.2 & $33.3^{*}$ & $52.4^{*}$ & 62.3 & $97.0^{*}$ & $98.6^{*}$ & 53.9 & 99.5 & $34.3^{*}$ \\
\hline & Oro Rico & $27.8^{*}$ & 80.0 & 36.5 & 84.0 & 63.6 & $97.9^{*}$ & $97.1^{*}$ & 52.3 & $6.3^{*}$ & $29.5^{*}$ \\
\hline & Guayamesa & $27.3^{*}$ & 87.5 & 29.3 & 42.1 & 66.0 & $97.8^{*}$ & $97.8^{*}$ & 54.8 & $1.0^{*}$ & $40.5^{*}$ \\
\hline
\end{tabular}

${ }^{1}$ Percent increase.

${ }^{2}$ Not detectable. 
As in $\mathrm{Na}$, and for the same reasons, the difference in $\mathrm{Cl}$ content between processed and raw dry beans was highly significant. The average $\mathrm{Cl}$ increase was $98.3 \%$. No significant differences in $\mathrm{Cl}$ content were found among selections or among varieties.

There was a highly significant difference in $\mathrm{K}$ content between raw dry and processed beans in the three classes. However, no significant differences were found among selections. The average $\mathrm{K}$ retention was $55.4 \%$, higher in the pinto selections.

No significant differences in protein content were found among bean selections or between raw dry and processed beans. However, the protein content of the white beans was highest. The average retention percentage was very high (96\%). Thirteen selections showed a little increase in the protein content. The average percent increase was 3.5. The increase detected may be due to analytical error.

Except in the striped class, no significant differences were found in fat content between raw and processed beans. No significant differences were observed among bean selections. However, of the 22 bean selections studied, 15 of them showed an increase in fat content. The average fat increase was $26.6 \%$. The tendency in white selections was to decrease in fat content. Aside from analytical errors, no explanation is found to account for this behavior.

Summing up, it can be said that $\mathrm{Ca}, \mathrm{Na}$, and $\mathrm{Cl}$ content of the bean selections studied were higher in processed beans than in dry beans while the amounts of $\mathrm{Mg}, \mathrm{P}$, and $\mathrm{K}$ were lower. No explanation may be advanced regarding the changes in fat content. It can also be said that the $\mathrm{Fe}, \mathrm{Mn}$ and protein content remained constant.

White beans were the highest in most of the nutrients examined; striped beans were second highest.

With few exceptions, the data obtained in this study agree with those reported in the literature $(2,4,8)$.

\section{RESUMEN}

Se evaluaron 22 selecciones de habichuelas de las clases marcadiablo (coloradas), blanca y pintas (galanas). Se estudió el efecto de la conservación comercial en latas sobre varios nutrimentos de la habichuela. Se analizaron muestras antes y después de elaborarlas.

Los contenidos de $\mathrm{Ca}$, $\mathrm{Na}$ y $\mathrm{Cl}$ en las habichuelas aumentaron significativamente con el procedimiento. El aumento en Ca puede atribuirse a que el agua utilizada lo contiene. El contenido de $\mathrm{Na}$ y $\mathrm{Cl}$ aumentó porque las habichuelas se envasaron en agua de sal al $2 \%$. El contenido de $\mathrm{Fe}$ aumentó en algunas muestras. El aumento en hierro puede atribuirse a su presencia en el agua o a la absorción de Fe del envase. 
Los porcentajes de retención de Mg, Fe, Mn, P y K fueron de 89, 95, $89.8,67.4$ y 55.4 , respectivamente.

Con muy pocas excepciones, los resultados obtenidos en este estudio concuerdan con otros efectuados por otros investigadores.

\section{LITERATURE CITED}

1. Association of Official Agricultural Chemists, 1975. Official Methods of Analysis, 12th ed, Washington, D.C.

2. Augustin, J., Beck, C. B., Kalbfleish, G., Kagel, L. C. and Matthews, R. H., 1981. Variation in the vitamin and mineral content of raw and cooked commercial Phaseolus vulgaris classes. J. Food Sci. 46 (6): 1701-6

3. Barrat, B., 1973. Nutrition: 2, Effect of processing, Food in Canada 33 (2): 28-31.

4. Colón de Reguero, L. and Rodríguez de Santiago, S. M., 1978. Tabla de Composición de Alimentos de Uso Corriente en Puerto Rico, Editorial Universidad de Puerto Rico, Río Piedras, P.R.

5. Elkins Jr., E. R., Kemper, K., and Lamb, F. C., 1976. Investigations to determine the nutrient content of canned fruits and vegetables, National Canners Assoc. Research Foundation, Washington, D.C.

6. Fiske, S. H., and Subbarow, Y., 1925. Colorimetric determination of phosphorous, J. Biol. Chem. 66 (2): 375-400

7. Goddard, M. S. and Matthews, R. H., 1979. Current knowledge of nutritive values of vegetables, Food Technol. 33 (2): 71-3.

8. Halaby, G. A., Lewis, R. W., and Rey, C. R., 1982. Variation in nutrient content of commercially canned legumes, J. Food Sci. 47(1): 263-6.

9. Hein, R. E. and Hutchings, I. J., 1975. Influence of processing on vitamin-mineral content and biological availability in processed foods, in nutrients in processed foods. Vitamin-Minerals, Am. Med. Assoc. 59-68, Publishing Science Group, Acton MA.

10. Kramer, A., 1974. Storage retention of nutrients, Food Technol. 28 (1): 50-1, 53-6, 58, 60.

11. - and Twigg, B. A., 1966. Fundamentals of Quality Control for the Food Industry, The AVI Publishing Co., Westport, CT.

12. Labuza, T. P., 1973. Symposium: Effects of Processing, Storage and Handling on Nutrients Retention in Foods. 2. Effects of dehydration and storage, Food Technol. 27 (1): 20-1, 23, 25-6, 51 .

13. Larmond, E., 1970. Methods for Sensory Evaluation of Foods, Publ. 1284, Canada Dep. Agric.

14. Lund, D. B., 1982. Influence of processing on nutrients in foods, J. Food Protection 45 (4): $367-73$.

15. Riera A. and Rivera-Nuñez, J. 1965. Automatization Applied to Chemical Analyses in Foliar Diagnosis, IX Congreso Latino-americano de Quimica, San Juan, P.R.

16. Rubins, E. J., 1966. Standard Methods of Chemical Analysis 6th ed, Vol. 3-Instrumental Methods, Part B, Welcher, F. J. Ed, Chapt. 62-Soils, pp. 1865-80, D. Van Nostrand Co., Inc., Princeton, N.J.

17. Russell, J. A., 1944. The colorimetric estimation of small amounts of ammonia by the phenol-hypochlorite reaction. J. Biol. Chem. 156: 457. 